Research Note

\title{
Appraising Romania's Legal and Institutional Framework for the Implementation of the Juncker Investment Plan
}

\author{
OAna CRistina Popovici \\ Corresponding author: popovici.oana@yahoo.com \\ Romanian Academy, Institute for Economic Forecasting \\ Bucharest University of Economic Studies \\ JRomania

\section{Adrian Cantemir Calin} \\ Romanian Academy, Institute for Economic Forecasting \\ Bucharest University of Economic Studies \\ Romania
}

\section{About the authors}

Oana-Cristina Popovici is a senior researcher at the Institute for Economic Forecasting, the Romanian Academy. She obtained her Ph.D degree in 2013 with a thesis on "Foreign direct investments analysis in the new European Union member states", in the field of International Economics and Business. She continued her research with the postdoctoral studies, completed in September 2015. Currently, she is an assistant professor at the Faculty of International Economic Relations. Her main topics of interest are foreign direct investments, public policies, economic competitiveness and European economics.

Adrian-Cantemir Călin is a senior researcher at the Institute for Economic Forecasting, Romanian Academy and lecturer at the Bucharest University of Economic Studies. He holds bachelor degrees in both International Business and Economics and Finance and a Master's degree in International Business Management. He obtained his Ph.D degree in 2013 with a thesis on Credit Risk Assessment in Central and Eastern Europe and completed his postdoctoral studies in the Romanian Academy. His main research interests include quantitative finance, risk management (especially credit risk modeling), financial derivatives, monetary policy, quantitative easing, and macroeconomic forecasting. 


\section{Aabstract}

In this paper, we assess Romania's position in terms of legal and institutional needs for ensuring the functioning of the European Fund for Strategic Investments, as Romania is one of the countries that lost the start of the Juncker Plan. The analysis we provide points to several shortcomings that threatened the application of the additionality principle: an inoperative public-private partnership law, the absence of a national promotional institution, difficulties in establishing connections between the public and the private entities. Based on the comparison between the European Commission's requirements for enhancing the implementation of the Juncker Plan and the existing situation in Romania, we provide several public policy measures for capitalizing the potential of the Juncker Plan. The main findings indicate the need of a functional legislative framework that regulates the institutional public-private partnership contract and the establishment of a public-private partnership unit with high visibility for the private actors in the institutional machinery; the construction of investment platforms for improving the involvement of private environment in the economy; and diminishing the time for establishing a national promotional bank, as it represents the institution that connects these instruments and has an important role in their functioning under the auspices of the Juncker Plan.

Keywords:Juncker Investment Plan, Public-private Partnership, Investment Platform, National Promotional Bank, European Fund for Strategic Investments

JEL codes: H83, M10, O52

\section{Introduction}

In June 2015, in the midst of a hard recovery after the economic crisis that began seven years earlier, the European Parliament approved the implementation of a major Investment Plan for the entire European Union (EU), bearing the name of the President of the European Commission, Jean-Claude Juncker. The Plan was considered one of the solutions for a Community in an urgent demand for investments, as its aim was to mobilize the important amounts of private funds not released on the markets due to a high lack of confidence, without an exacerbated increase in public debt. Therefore, domestic institutional efforts were directed towards enhancing the collaboration between the public and the private sectors and the support of the private organization forms and private initiatives with the help of three main instruments: the publicprivate partnerships (PPPs), the investment platforms and the national promotional banks.

Not all the countries managed to benefit to a similar extent from the EU initiative. The short timetable of the Plan (which was announced in July 2014 and implemented one year later) tended to favour the countries already prepared for accessing financing (Gordon, 2017). The lack of a legislative provision related to a regional distribution of the funds intensified the fears of growing development disparities between countries (Rubio et al., 2016). While the European Commission relied on the market requirements and the principle of additionality as two key pillars for ensuring the allocation of the funds in the most needed areas, 
such initiatives might prove not to be enough when countries are confronted with a lack of sophistication in financial institutions and limited experience in running European Investment Bank (EIB) projects (as suggested by Rubio et al., 2016). In addition to this, domestic turbulences could further delay the efforts of the national institutions in capitalizing the potential of the Plan. When referring to additionality, the European Commission relates to supporting those projects that are channelled in the areas or sectors where investments are below the optimal level, meet market failures or would not be financed otherwise, implying a higher degree of risk than the ordinary operations financed by the European Investment Bank.

Romania faced, to a large extent, all these obstacles in implementing the Juncker Plan, which lead to poor performance in mobilizing investments. The report of the European Commission issued in June 2018 ranks Romania on the 23rd place in the EU regarding the GDP's share of the total investment set to be triggered and the last place among the new EU Member States. At present, Romania is enrolled in a convergence process meant to reduce the development gap as compared to the rest of the Member States. In this context, the goal is to harness the investment opportunities and to tune legal and institutional frameworks for effectively responding to similar measures.

The rest of the paper is structured as follows: the next section will briefly present the structure and the advantages of the Juncker Plan as a funding source, followed by a brief section of methodology for emphasizing the way in which the assessment of the conditions in Romania is carried out. The main body of the paper is focused on the following two parts, whose aim is to provide a mirror comparison between the legislative and institutional requirements for enhancing the implementation of the Juncker Plan and the existing situation in Romania.

Therefore, the subsequent part reviews the literature and the EU legislation with the aim of presenting the main instruments envisaged by the European Commission for ensuring the cooperation between the public and the private sectors, which could enhance the implementation of the Juncker Plan. The objective is to make clear the needs in term of legislative, institutional and political strategy for enhancing the potential of these instruments in practice. To our knowledge, this is among the few academic articles that provide a comprehensive image of the tools needed for promoting the use of the Juncker Plan in less financially developed countries.

The following part assesses the progress of Romania in adapting the legislation, institutions and political strategies related to these instruments. A comprehensive analysis and evaluation of the legislation is carried out in this regard.

Based on the previous comparison, in its last part, the paper provides several measures regarding Romania's public policy needs for capitalizing the potential of the Juncker Plan, which could be helpful for other Member States, too. The final section concludes, summarizing the main findings of the paper.

\section{Briefly Description of the Juncker Plan}

In brief, the aim of the Juncker Plan is to mobilize investments up to EUR 315 billion from both public and private sources starting from an EU guarantee of EUR 21 billion. The instrument for facilitating such an 
approach is the EFSI, operated by EIB. The EFSI support is focused on two directions: the infrastructure and innovation window, covering high risk investment projects in strategic sectors (EUR 240 billion) and managed by the EIB, and the SMEs window, where the funds are granted to SMEs and medium-sized companies with less than 3000 employees through the European Investment Fund (EUR 75 billion).

The Plan is built on three pillars, the first being the one mentioned above, aiming to mobilize finance for investment. The second pillar is focused on supporting investments in the real economy. In order to ensure this objective, EFSI benefits from the support of the European Investment Advisory Hub (EIAH), which provides technical assistance for the project promoters and enhances the collaboration between the institutions in the Member States. Also, the European Investment Project Portal (EIPP) aims to ease the submission and selection of the projects. The last pillar targets the business environment at the European level and requires measures such as completing the Digital Single Market, the Energy Union and the Capital Markets Union (more details are provided in Calin et al., 2017). In addition to this, each Member State has to deal with the obstacles that hinder doing business, such as "removing barriers to investment, ensuring that there is no discrimination based on whether the management of projects is private or public (...) and enhancing regulatory predictability" (Regulation (EU) no. 2015/1017, p. 12).

The potential of the Juncker Plan is estimated to add between EUR 330 billion - 410 billion at the EU GDP (according to Crespo, 2015) and to employ between 1.3 million (according to the European Commission) and 2.1 million new persons (according to the International Labour Organization, cited by Crespo, 2015). An extensive explanation regarding the functioning of the Juncker Plan is presented in Albu et al. (2016).

From several points of view, accessing funding through the Juncker Plan should be easier than through the European Structural and Investment Funds, given that it is built on an infrastructure that already exists or should exist in the EU countries. For example, for the functioning and absorption of the European Structural and Investment Funds, Member States are needed to build special institutions, such as a managing authority, a certifying authority and an auditing authority for each operational program, each with their own responsibilities (Regulation (EU) no.1303/2013, paragraph 106). The implementation of the Juncker Plan does not expressly request any new bodies or institutions. However, in order to fully benefit from the funds provided and to facilitate the cooperation between the public and the private environment, the EU countries should adapt their legal and institutional framework. There are several instruments that must perform well at national level for ensuring the functioning of the Plan, according to the rules describing the way in which EFSI is running: the public-private partnerships (PPP), the investment platforms and funds and the national promotional banks (NPB) or institutions.

\section{Methodology}

This paper focuses on the legal and institutional gaps Romania encounters in the functioning of the Juncker Investment Plan. For achieving this goal, the methodology used in this paper is structured as follows: firstly, we analyse the European requirements for the implementation of the Juncker Plan. We identify that the public-private partnerships, the investment platforms and the national promotional banks or institutions are 
the main instruments envisaged for mobilizing finance through the Juncker Investment Plan. Therefore, based on the existing legislation and the literature review, we describe the prerequisites for the implementation of each instrument.

Secondly, the situation in Romania is assessed in relation to these three axes, in order to identify the gaps in legislation and at institutional level that represent obstacles in carrying out investments through the Juncker Plan. The comprehensive investigation and evaluation of the existing legislation is accompanied by the analysis of the specific literature.

Finally, we provide several public policy measures that Romania could apply for covering the legislative, institutional and strategy needs in each area, which are based on the former comparison and analyses.

\section{Ways of Enhancing the Cooperation between the Public and the Private Sectors}

The Juncker Plan represents more than the structure described below. According to Mertens and Thiemann (2018, p.3), "the Investment Plan creates a coalition of supranational institutions, national governments, development banks and private financial actors, developing and supporting the new financial opportunity spaces created by regulatory changes". The legislation for the functioning of the Juncker Plan lead us to identify three instruments that must be developed if the Member States want to be integrated in this network, focused on the strengthening the cooperation between the public and the private sectors: a clear legal basis for the development of the public-private partnerships (PPP), support for the investment platforms and the establishment of national promotion banks.

\section{The Public-Private Partnerships}

The PPPs are an important tool in the revival of the collaboration between the public and private environments and a solution for the implementation of large projects in areas such as transport and energy infrastructure. This practice started being used at the European level after the economic crisis, especially because it maintains the public debt under control. OECD (2012) defines the PPPs as "long-term contractual arrangements between the government and a private partner whereby the latter delivers and funds public services using a capital asset, sharing the associated risks" (p. 18).

Still, the PPPs are associated with high complexity and important risks. Therefore, the whole PPP process must be well designed and monitored, a burden that falls upon governments and public decisionmakers.

At European level, the European PPP Expertise Centre (EPEC) was launched in September 2008 as a collaborative network formed by the EIB, the European Commission, the 28 EU Member States and the EU candidate countries. The main aim of the EPEC is to help the public authorities to develop PPPS by facilitating the exchange of good practices, experience and analysis regarding all aspects of PPPs. The EPEC activity is structured on three pillars (Barrett and von Thadden, 2011): 
- Providing policy and program support in order to identify the role of PPPs in their country and to build concrete PPP programs;

- Offering services related to the needs of the countries regarding PPP, market updates and PPP performance analysis.

- Establishing networks between the institutions dealing with PPPs and identifying best practices.

There is not a general consent in the literature and practice related to the impact of PPPs. Mullin (2002) states that the academic literature generally is more prone in pointing to the risks and costs such initiatives raise, while Guldbrandsen (2002), and Mullin (2002, p.17) warn that the public partner is usually more disadvantaged. Such slippages could be addressed by paying attention to the selection of partners and the share of responsibilities in the pre-development stage of the project (Mullin, 2002), even more as, despite low performances in some cases, PPPs continue to be seen as a method for financing large-scale projects (Garg and Garg, 2017).

Giving the high potential of PPPs, there are some relevant issues that must be completed in order to have totally functional public-private collaboration.

\section{i. Legislation Needs}

In its principles regarding the public governance of PPPs, the OECD's (2012) first recommendation is to have "a clear, predictable and legitimate institutional framework supported by competent and well-resourced authorities" (p.8) regarding the PPPs, as well as other complementary regulations that affect the process. The PPP legislation should be established based on consultations with the potential stakeholders, the labour unions and non-governmental organizations (NGOs) that activate in this domain.

A vital characteristic of the laws affecting the PPP framework is their transparency, clarity and the ease of being implemented. This is a domain where bureaucracy must be minimized, while the new regulations would be approved after careful evaluations. Still, this will not impede the permanent revision of the regulations affecting PPP in order to ensure their cost efficiency, the adaptation to changes in the economy and the capacity to deliver outcomes in compliance with the public policy objectives. The signals coming from the private sector and the practical experience could adjust the regulation of the PPP process.

\section{ii. Institutional Needs}

Given the complexity of the PPP process, EIB suggests the establishment of a specialized entity meant to select, prepare, deliver and manage PPP projects. In order to increase its visibility, it should be integrated among governmental institutions. Based on the evaluation of the functioning of PPP units in 18 countries member of EPEC, a good implementation of PPP projects suggests that three main functions should be assigned to the PPP entity (EIB, 2014):

- Support for PPP policies and related activities. This function is mirrored in the coordination of PPP activities at the governmental level for achieving several purposes, such as: ensuring the delivery of results; involvement in the design and implementation of consistent laws and regulations regarding the PPP activities; providing high quality and relevant procedures for the prevention of potential problems in the PPP 
process; ensuring the ability to drive public sector reforms in terms of selection, preparation and delivery of PPP projects; developing standardized documents for the whole PPP process; increasing the awareness on PPP projects; assessing the costs and benefits of PPP projects; using the experience from previous projects.

- Support for the delivery of the PPP project. The PPP unit will provide counselling to the public procurement authorities concerned in developing a PPP project in order to be aware of the needs in terms of resources, time and expertise for delivering a sound PPP project. In this way, the interested authorities will be better equipped for identifying, determining and managing the needed combination of public and private expertise for preparing and developing the PPP projects. Also, the PPP entity will provide technical support for solving the potential problems of the project in a reasonable period of time.

- Approval and quality control. This function could be exercised in different moments of the PPP project implementation: when the decision to launch a PPP project is taken, at the moment of starting the procurement or the purchase for the PPP project. For this purpose, the PPP unit must be endowed with the necessary authority and technical expertise. This way of acting can prevent the implementation of weak projects and the consistency with the PPP policy is ensured.

EIB notes that different combinations of these functions are used at different levels in the process of implementing the PPP project.

\section{iii. Political Strategy Needs}

Both OECD (2012) and the best practices recommend that the PPP projects must be developed in accordance with the strategic goals of the government. In this way, the costs and outcomes could be assessed more easily, but also the potential stakeholders could manage their own interests and objectives. Such an approach would bring more predictability to the PPP's strategy. This can be done by permanently updating the list of projects that are envisaged to be realized through PPP.

Also, the EIB (2015) recommends implementing PPP programs that reunite several individual and smaller projects with a common aim or in a common sector, in order to be delivered in a coordinated manner. This procedure has the advantage of removing the bureaucracy and red tape by using a standard documentation and a similar methodology for each project. The result is quantified in lower costs and time required for the PPP procedure. The PPP program could be coordinated at governmental or regional level, the most suited for ensuring the achievement of common goals.

\section{Investment Platforms}

The investment platform is formed by several entities joined by the common goal of financing specific investment projects. In an EY report, the investment platforms are seen as a "global phenomenon" with a very strong demand due to the growth of the adult wealth (Ernst and Young, 2014).

In short, the aim of the EIB and the European Commission regarding the investment platforms was to gather "co-investment arrangements structured with a view to catalysing investments in a portfolio of projects (as opposed to individual projects) with a thematic or geographic focus" (European Commission and European Investment Bank, 2016, p.4). The participating entities could originate in the public area (such 
as public authorities), in the private sector, in the academic area or could be representatives of the civil society. The EU Regulation also encourages the existence of multi-country platforms as a way of promoting cross-border projects. The effort of this joint group of investors could benefit from the EU guarantee in order to finance their projects, having the main advantage of a more effective risk-sharing among the participants and a reduction in costs, especially the transaction and information costs (Albu et al., 2016). A specific type of investors' organization is the crowdfunding platform that could be used for establishing the connection between the interested investors and the fund collector. For the public investment platform, the advantage is that the amount invested is not causing budgetary pressures, if the EU regulation concerning in this area is respected.

There are two types of involvement for the EFSI fund in the investment platforms:

- Providing funding through the EU guarantee in order to support the development of the investment project;

- Providing credit enhancement, if necessary, leading to a specific portfolio or projecting risks' mitigation and facilitating the entry of private co-investors.

There are several roles an investment platform is endowed with, according to European Commission and EIB (2016):

- Facilitating the crowding-in of the investors for financing projects in areas where there are market failures.

- Covering projects in different regions: the platforms could support either the investment projects in one member state or in several Member States, in a single region or in different regions, as part of one or more Member States.

- Also, the platforms could envisage one sector for being financed or multiple sectors.

As forms of support, the platforms running under the Juncker Plan could benefit from several financing products: equity and quasi-equity investment in projects or funds, loans and guarantees for the projects, guarantees and counter-guarantees to intermediaries (p. 7) and also advisory services.

There are three parts involved in the management of an investment platform (IP), as presented in Fig. 1. The sponsor(s) of the IP's role is to establish the purpose of the platform, namely the investment need, to draw the geographical and sectoral covering, to identify the sources of funding and to decide the risksharing, the management rules, and the criteria for remunerating investors. It can also contribute with funding. A wide range of institutions could be the sponsors of an investment platform, starting with the NPBs to Sovereign Wealth Funds, as can be seen in Fig. 1. The task of the project promoter is to propose projects to the IP that will be selected by the sponsors. Either public or private entities could assume the role of a promoter. The platform manager will ensure the daily management of the platform and the financing of the projects selected by the sponsors based on a careful analysis of their economic rationale, soundness and financial robustness. The platform manager is appointed by the sponsors and could be either an independent fund manager, either an NPB, a commercial bank, one of the platform sponsors or even the 


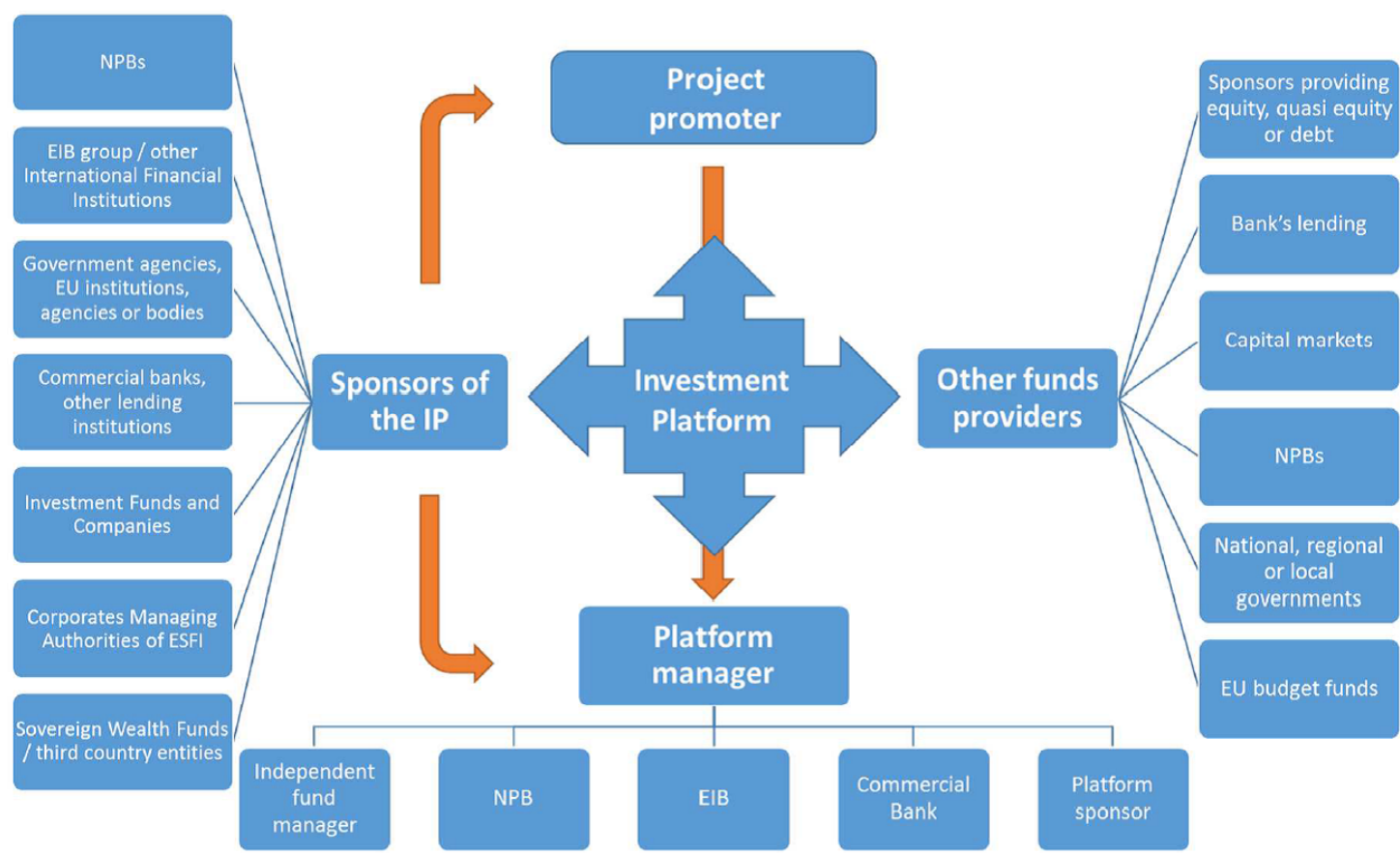

Fig. 1 The functioning of an investment platform

Source: Authors' computations, based on the information provided by European Commission and European Investment Bank (2016).

EIB. Finally, the investment platform counts on the other funds providers for accumulating the amount needed for the development of an investment project. It is actually their contribution that makes up the most of the platform's funding. Their typology is presented in Fig. 1.

\section{National Promotional Banks}

The NPBs are critical in guiding investment in the areas where there is an important lack of financing (Regulation (EU) no. 2015/1017). The NPBs have the main advantage of knowing the local area, the sectors in need of financing and the way the local institutions and companies are conducting their activity. This is the reason why the European Commission strongly advises the Member States to set up such types of institutions, according to the Communication launched on July 22, 2015, regarding the key role they can play in the implementation of the Investment Plan at the European level (European Commission, 2015).

In a more usual term, an NPB overlaps to what was known so far as the development bank or development financial institutions (Wruuck, 2015). The EFSI Regulation defines NPBs as "legal entities carrying out financial activities on a professional basis which are given a mandate by a Member State or a Member State's entity at central, regional or local level, to carry out development or promotional activities" (Regulation (EU) no. $2015 / 1017$, p. 10). While the definition is merely general, there are also other international organizations that provide a more concrete explanation of the term. The study conducted by De Luna-Martinez and Vicente 
(2012) under the auspices of the World Bank adheres to the definition according to which a development bank is "a bank or financial institution with at least 30 percent state-owned equity that has been given an explicit legal mandate to reach socioeconomic goals in a region, sector or particular market segment". Still, UN (2005) provides examples of NPBs that are in private ownership, certifying that, in 2002, there were 11 development banks in private ownership.

A distinctive feature of the NPBs is their financing oriented towards long-term projects. UN (2005) states that their activity could be described following three directions: specific purposes of the economic development, clear social objectives and support for regional integration. Therefore, NPBs could be considered as "financial institutions set up to foster economic development, often taking into account objectives of social development and regional integration, mainly by providing long-term financing to, or facilitating the financing of, projects generating positive externalities" (UN, 2005, p. 10).

Of a real help in identifying the characteristics of an NPB are the activities that institutions subscribing to this notion are carrying out all over the EU. Although their range of interests is quite heterogeneous (Wruuck, 2015), there are several common characteristics (according to Wruuck, 2015 and De Luna-Martinez and Vicente, 2012):

- They are typically public institutions;

- Their objectives are focused on supporting several socioeconomic goals, usually supporting SMEs, agriculture, international trade and infrastructure. Still, the wide range of activities leads to a classification of NPBs in "sectoral" (focusing on specific sectors), "universal" or "Exim banks" (financing the activities of export and import, UN, 2005).

- They support entities who meet difficulties in covering their financial needs;

- They cover the market failures, such as the asymmetric information, the weak competition and the externalities (according to the European Commission, 2015) that generate lack of investments in several areas implying large projects where the benefits are more challenging to be assessed (such as infrastructure, environment, education, research and development), difficulties in identifying viable projects (for example for SMEs) and which therefore imply additional costs that the other institutions are not interested to bear.

- They have a countercyclical role, by providing financing in hard economic periods, where sources of financing are temporarily difficult to access. Fig. 2 extensively describes the role of NPBs.

The main divergences among the development banks rest in the share owned by the state, their client and sectors targeted, the modality of lending, the funding mechanisms, their role and involvement in the domestic economy (De Luna-Martinez and Vicente, 2012), which are inevitably adjusted to the characteristics of each country.

Besides their role in guiding the funds more effectively, NPB could also be part of the investment platforms, thus indirectly accessing funds. Moreover, the NBP ensures the presence of the Member States at the cooperation sessions with the EIB Group, the European Commission and the rest of the NBPs in EU. In this way, a Member State has the possibility to establish investment relations in a cross-border investment 


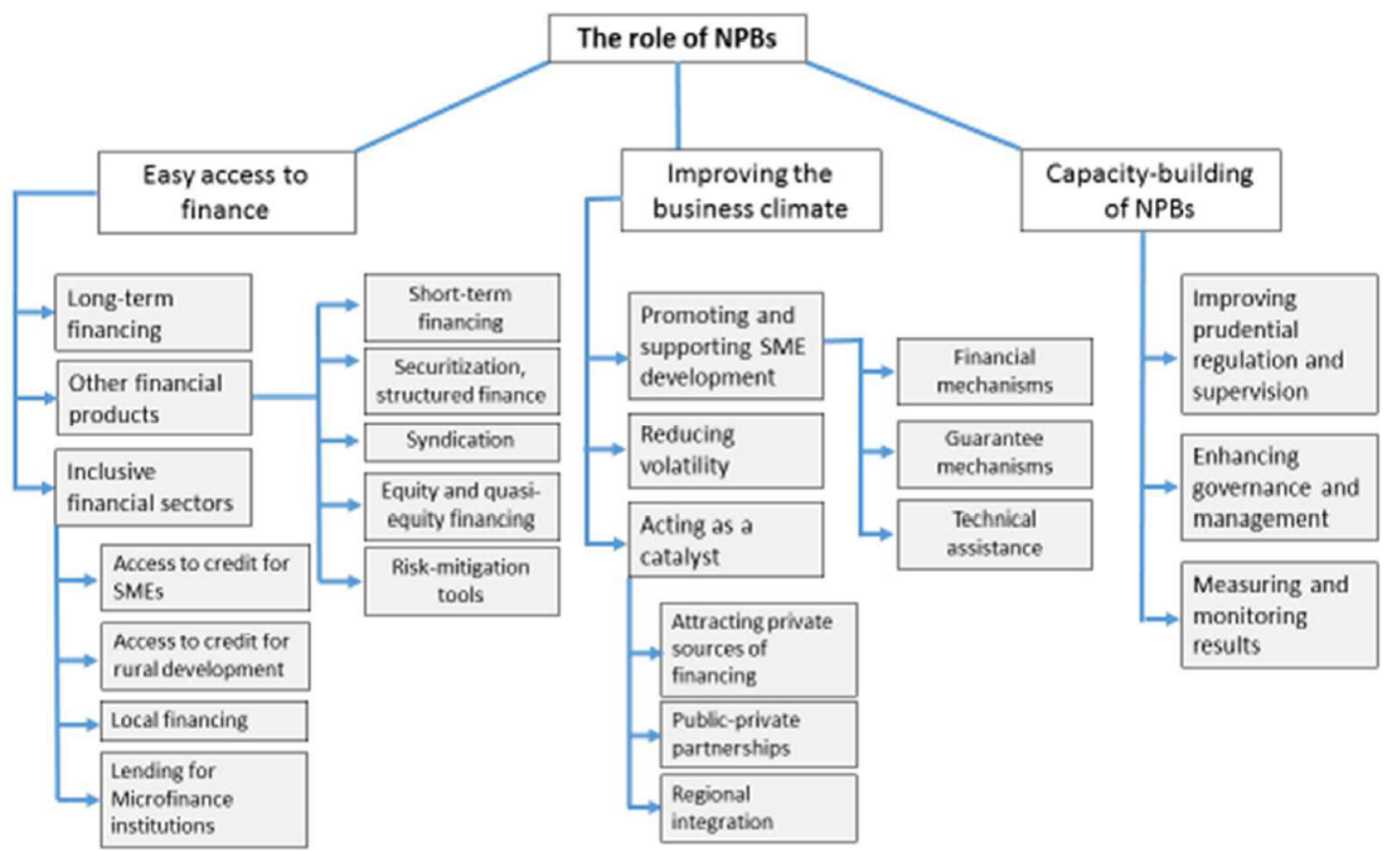

Fig. 2 The role of NPBs

Source: Authors' computation based on UN (2005)

platform, to learn from the good practices shared by other NBPs or to be part of the common activities at the EU level (Albu et al., 2016).

\section{Assessing the Situation in Romania}

\section{The PPP's Status Quo}

Pianta (2016) sees the establishment of EFSI as the first step in the development of a larger industrial policy, which starts with the investments in infrastructure and production systems (p. 315). Abiad et al. (2015) relate to the aim of the $\mathrm{EU}$ to increase the investments in infrastructure as an incentive for reinvigorating growth. Attracting private investors in such large and high-risk projects is not an easy task. One of the first needs is the establishment of clear PPP legislation.

In Romania, the PPP could represent an opportunity for achieving major investments, especially in the areas of energy and transport infrastructure, sectors that were also targeted through PPP transactions at the European level. Such a solution proved reliable for covering both the diminished capacity of the public sector for financing due to the economic crisis and the need to keep public debt under control. In addition to this, the advantage of a PPP project resides in the contribution of the private sector know-how.

However, besides these benefits, several sources indicate that no PPP project was launched in Romania, although the first legislative reference to the PPP process dates back in 2002 (Albu et al., 2016). The 
explanation lies in the lack of functionality of PPP laws that Romania tried to implement. PPPs were first regulated by the Government Ordinance no. 16/2002 regarding the public-private partnership contracts. Subsequently, the regulation was abrogated in 2006; due to the unclear and defective formulation of the law, no PPP project was realized in this period. The Romanian practice was devoted to the use of the concession contracts, regulated by the Government Emergency Ordinance no. 34/2006 on the award of public procurement contracts, public works concession contracts and service concession contracts. Therefore, the legislative references rather regulated the contractual PPP (based on the concession contract) and not the institutional one, which involves the creation of a public-private mixed capital entity meant to finance public projects. In November 2010, the Law No. 178/2010 came into force and a series of subsequent emergency ordinances substantially adjusted the initial regulations. Unlike the previous ones, this law regulates the existence of a PPP project company whose capital is owned by the public partner and the private investor, responsible for the management of the PPP contract. The aim of the PPP is to "design, finance, build, rehabilitate, modernize, operate, develop and transfer a public good or service, where appropriate". These regulations from 2010 draw Romania closer to the European practice, where the institutional PPP is more frequently used in order to ensure infrastructure development, the provision of social services, and the construction of schools, public healthcare units or prisons. Unfortunately, the new law did not have effects on conducting PPP projects in Romania. The main failure of the law in 2010 was considered the parallel application of another law governing public works and public services concessions. In addition to this, the law required funding only from the private partner, while the public one would have to provide contribution in kind, without involving public funding (Albu et al., 2016).

Only in May 2018, an Emergency Ordinance of the Government no. 39/2018 established the implementation of the PPP. Among the novelties, the legislation states that the PPP could be established for the provision of both goods the services. Also, a special financing fund for PPP contracts at the national level is to be established in maximum one year.

\section{The Investment Platforms Status Quo}

The investment funds in Romania are regulated by Law No. 297/2004 on the capital market, and represent the collection of funds from several investors, which are then invested in different types of financial instruments such as stocks, bonds, derivatives or deposits. Very frequently, state bonds are issued in order to refinance debt and to finance the budgetary deficit. In order to achieve the goal of supporting the investment in the real economy, we consider that, firstly, the investors' choice should be focused on the corporate and municipal bonds. Corporate bonds are issued by companies that need financing to develop new investment projects or to expand their activity. The role of the municipal bonds is to finance investment projects such as building new schools, cultural institutions, repairing or ensuring the maintenance of the public assets.

Romania lags behind in adopting such instruments and in developing investments platforms, but Rinaldi and Nunez Ferrer (2017) draw the attention that the situation in Europe is quite similar, their use being enforced once with the launch of the Juncker Plan.

At the European level, there is a trend in using crowdfunding, a method of collecting funds from several 
investors (including small ones) through the internet, providing in return various incentives. The online platform is essential for establishing the connection between the investors and the fund collector. Besides, its role is to gather small-sized projects (Rubio et al., 2016) and to focus the funding in either a geographical region, either in a specific sector (Rinaldi and Nunez Ferrer, 2017), which would represent an advantage for a small economy as Romania. Moreover, due to their additional role as special purpose vehicles, IPs also allow the sharing of risk between public and private institutions (Mertens and Thiemann, 2018).

\section{The Promotional Institution's Status Quo}

Mertens and Thiemann (2018) draw attention on the increased contribution of the NPB's in the EU strategy of creating a capital markets union and governing through financial markets. Their role is mainly oriented towards providing loans for the SMEs and the development of infrastructure, through different tools such as public guarantees.

At present, Romania does not have a development or promotional bank. Still, at the beginning of March 2015, the Romanian Government approved the Memorandum on "Information on the project for a national development bank", in which it is stipulated to initiate the process of expanding the mandate of EximBank in order to transform it into a development bank. In November 2015 the Law project on the functioning of the Romanian Development Bank - EximBank S.A. was launched and it was envisaged that at the beginning of 2016 the actual EximBank would take over as development bank. In December 2015, the Chamber of Deputies stated that it supports the initiative of the Romanian Government of extending the mandate of the Export-Import Bank EximBank Romania to carry out specific development bank operations and thereby transforming it into an NPB.

However, a Deutsche Bank research report (Wruuck, 2015) regards EximBank as a development financial institution. It is listed in this category given the assumption of the author on the specific features of a development bank as compared to other publicly owned banks, namely "the mission to promote economic development and other designated socioeconomic goals" (p.2). The EU documents are not providing any directions in this respect, simply admitting the existence of an NPB of any type. Still, EximBank was accepted and participated at the technical reunions with the representatives of EIB and the other NPBs in order to establish the implementation of the new mechanisms within the Investment Plan (Albu et al., 2016), practically assuming this role.

These mechanisms relate to accessing financing and portfolio guarantees granted by the EIB through EFSI, the opportunity to participate in capital investments made by the EIB in innovative projects of SMEs, etc. Moreover, the EximBank experts are already preparing to launch new financial products suitable to the EFSI profile and to the needs of the business environment in Romania. Given this facts, EximBank is ready to fulfill its role in the Juncker Plan. The establishment of an NPB will also entail the launch of investment platforms, as Rinaldi and Nunez Ferrer (2017) point to the partnership needed between these two types of instruments and Rubio et al. (2016) state the preference of the European Commission for NPB investments through IPs. Mertens and Thiemann (2018) support the role of NPBs in promoting PPP projects. Moreover, the advantage of involving the NPB is that such investments are exempted from the state aid rules (Mertens 
and Thiemann, 2017).

In addition, Rubio et al. (2016) see the NPB as a baseline condition for a successful implementation of the Juncker Plan, since it has a decisive role in ensuring the cooperation with the EIB in both providing technical assistance and an optimal allocation of public funds. The Juncker Plan relies on the expertise and knowledge of the domestic market for seizing investment opportunities (Mertens and Thiemann, 2017).

\section{Discussions Regarding Romania's Public Policy Needs}

\section{PPPs' Challenge}

Based on the situation described above for Romania and the characteristics mentioned earlier for efficient investments through PPPs, there is an urgent need of:

- A PPP law whose quality is mirrored in its effective functioning. Romania just adopted a new Emergency Ordinance establishing the functioning of the PPPs, therefore it is too early to evaluate its impact. Still, more flexibility is needed in adopting changes if such measures are required after release. As discussed above, EPEC is a good source of information for the establishment of PPP legislation and for adopting good practices that can be further adapted to the national particularities.

- A PPP unit to handle all the steps necessary to the implementation of a PPP project, encompassing the functions envisaged by EIB (2014) and previously presented. Its structure could be built on the format of the Department of Foreign Investments and PPP within the working apparatus of the Government, but it should be more visible for the potential private partners. The PPP unit should be connected with economic dynamics, ready for immediate remediation of problems, enforcing the implementation of PPP projects, able to cooperate with the whole interested institutions that ensure the PPPs progress.

- Strategically planning of PPP projects, for increasing the confidence of the private sector and the development of PPP programs that contribute to an easier delivery of several smaller PPP projects.

\section{Challenges Regarding the Investment Platforms}

In Romania, there is a need for adapting the legislative framework for allowing the creation of such investment platforms in order to enhance private initiative. Still, the success of a functioning platform lies not only in adopting the necessary institutional and legal regulations, but also in maintaining and improving an environment favourable to the business development. Therefore, in addition to attracting investments through EFSI, Romania should equally focus on creating an enabling environment for investment, corresponding to the third pillar of the Juncker Investment Plan. The most urgent measures needed in this area are (according to Albu et al., 2016):

- Creating investment platforms using the crowdfunding model in order to connect the funding 
supply and demand. The NPB or a state fund could take the initiative and be the first to organize an investment platform for attracting EFSI funding. Romania could use the example of the United Kingdom and Italy, which have crowdfunding legislation, and to adapt it to domestic circumstances. In addition, the EIAH provides assistance in the launch of these platforms. The state may be involved in the management of the online platforms and the supervision of the integrity of the companies enrolled on these platforms, in need of funding or seeking to provide financing. In Italy for example, such a platform is managed by CONSOB, the Italian Financial Authority.

- Adapting the legislation for providing incentives to companies investing in such platforms. In the case of the projects where state investment objectives are carried out, the contribution of private investors can be rewarded through a series of financial incentives, such as the exemption from duties and taxes for a determined period or for specific amounts of money. For private investors serving the financing needs of another company, the practice of European states allows to be rewarded with a share of the profit or of the business. The investment platforms are appropriate not only for important investments but also for small ones, in order to meet the financing needs of innovative SMEs, for example. In addition to this, various areas could be financed as, for example, the activity of a specialized research institute on a particular topic. In these cases, as the good European practice indicates, there can be different types of remuneration for private investors, not only financial incentives.

Romania could benefit from the help provided by the European Commission, who guarantees that both the crowdfunding and the public investment platforms could use the guidance and the technical assistance provided by the EIAH in the investment projects submitted for being financed through EFSI (European Commission and European Investment Bank, 2016).

\section{Challenges Regarding the Promotional Institution}

According to present planning, the Romanian development bank will be built after the model of the Polish Development Bank BGK, with enhanced skills in attracting European funds in the period 2015-2020 and higher involvement in infrastructure projects at the national and regional levels. From this position, EximBank will have the opportunity to be part of the implementation of the EU's strategic investment initiatives, including the Investment Plan of the Junker Commission, to work with the EIB to finance innovative SMEs or infrastructure projects that have difficulties in obtaining funding.

The main changes that EximBank will suffer once it became a promotional bank refer to its activity in the name and on the behalf of the state. A brief comparison between the present activities of EximBank and those to be carried out as a development bank are presented in Table 1. The new draft legislation establishes a clear boundary between the activity of the NPB as a commercial bank that is fully submitted to the regulatory requirements at the domestic and European levels, and its activity as an agent of the state. The complementarity between the two activities lies in supporting the strategic economic sectors in accordance with the policies of the Romanian Government (Romanian Ministry of Finance, 2015b). 
Table 1 Comparison between the Activities of EximBank at Present and its Duties as a Development Bank

\begin{tabular}{|l|l|l|}
\hline & As a development bank (or NPB) & At present \\
\hline Ownership & $\begin{array}{l}\text { A stock company, the Romanian state } \\
\text { holds at any time at least } 51 \% \text { of the } \\
\text { social capital. }\end{array}$ & $\begin{array}{l}\text { A stock company, in which the Romanian } \\
\text { state holds at least 51\% of the social capital. }\end{array}$ \\
\hline $\begin{array}{l}\text { Type of activi- } \\
\text { ties }\end{array}$ & $\begin{array}{l}\text { Activities developed in the own name } \\
\text { and its own account and in the name } \\
\text { and on the behalf of the state }\end{array}$ & $\begin{array}{l}\text { Activities developed in the own name and its } \\
\text { own account and in the name and on the be- } \\
\text { half of the state }\end{array}$ \\
\hline
\end{tabular}

Main changes as regards the activities developed in the name and on the behalf of the Romanian state:

\begin{tabular}{|c|c|c|}
\hline Customers & $\begin{array}{l}\text { Clients with a higher risk-profile that } \\
\text { provide more added value: newly } \\
\text { created companies, start-ups, SMEs, } \\
\text { NGOs, community development associ- } \\
\text { ations, local action groups etc. }\end{array}$ & Exporters and Romanian investors abroad \\
\hline $\begin{array}{l}\text { Financing } \\
\text { instruments }\end{array}$ & $\begin{array}{l}\text { Financing and co-financing, refinanc- } \\
\text { ing, guarantees, insurances, reinsur- } \\
\text { ance. }\end{array}$ & $\begin{array}{l}\text { - Guarantees for export; } \\
\text { - Interest rate subsidies; } \\
\text { - Financing and refinancing activities; } \\
\text { - Insurance and reinsurance for credits and in- } \\
\text { vestments; } \\
\text { - Other operations provided by law. }\end{array}$ \\
\hline $\begin{array}{l}\text { Funding } \\
\text { sources }\end{array}$ & $\begin{array}{l}\text { - Financial resources, such as finan- } \\
\text { cial resources made available by the } \\
\text { Ministry of Finance or the state bud- } \\
\text { get, revenues from privatization, re- } \\
\text { imbursable financing from domestic } \\
\text { and international markets, including } \\
\text { those from financial international in- } \\
\text { stitutions, governmental development } \\
\text { banks etc. } \\
\text { - Reimbursable financing contracted on } \\
\text { the behalf of the state (considered as } \\
\text { public debt). }\end{array}$ & $\begin{array}{l}\text { - The amounts specially allotted to support } \\
\text { exports from the state budget; } \\
\text { - The amounts collected within the limit of } \\
25 \% \text { of the foreign recovered from debtor coun- } \\
\text { tries; } \\
\text { - The net amounts from the insurance premi- } \\
\text { ums and those representing recoveries of the } \\
\text { credit insurance; } \\
\text { - The interest received from funds; } \\
\text { - Other sources. }\end{array}$ \\
\hline
\end{tabular}

Source: Compiled base on the documents provided by the Romanian Parliament (2000) and the Romanian Ministry of Finance (2015a, 2015b).

There is also a change in the types of clients or beneficiaries of the NPB: in the new format, the NPB will drive its support to customers with a higher risk profile than usual, but with the ability to create added value and new jobs, as required by the EFSI regulation, in order to respect the principle of additionality.

Therefore, Romania firstly needs a development bank. EximBank would be the first choice, as it is already involved in the Juncker Plan mechanism, but it could also be another institution. The problem is that by postponing the foundation of an NPB, Romania postpones its own development favoured by the launch of the Juncker Plan. Secondly, the activity and objectives of the NPB must be founded on the analysis that assesses market failures and identifies the areas of intervention, the range of products needed to fill those gaps, thus supporting the launch of new financial instruments at the disposal of the NPB. Seizing the 
opportunity offered by such an institution in the context of the Juncker Investment Plan, Latvia managed to get the approval for the establishment of its Single Development Institution at the beginning of June 2015, before the European Parliament' approval of the Juncker Plan.

The United Kingdom introduced in 1992 a scheme of Private Finance Initiative (PFI), functioning in a similar way to a PPP, through which the design, finance and operation of public projects were granted to private investors (Booth and Starodubtseva, 2015). Despite the well-known benefits, the disadvantages observed in practice related to higher cost of private finance than of government borrowing (the estimated interests' costs were more than twice higher for private investments, especially after the financial crisis) that could also emerge as a result of delays in the procurement process, difficulties in changing the contracts which are concluded for long-time period, therefore involving other costs for their termination. For redressing such problems, the system was reformed, the main changes being related to increased transparency and reliability, more control for the approval of major projects (Booth and Starodubtseva, 2015). In fact, the inappropriateness of PFI was warned earlier by Froud (2003), who affirmed that the state has the role of "planning and monitoring public services, of modifying policy, or working towards goals of equity and balanced interests" (p. 587).

Therefore, deeper control and monitoring of such projects involving private finance is needed. The government should assume the development of these initiatives in a coordinated manner, by developing strategies that state the overall purpose of the projects financed through private sources, their priorities, the maximum amounts each partner will invest, the complementarity with government's current projects as well as the final owner of the assets built in public-private partnership, as the final interest should be the well-being of the citizens. For a short period starting with 2013, Romania initiated the project to prioritize public investment, meant to identify the priority public investments, to allocate them the finance needed for being completed in a relevant period of time and to cease those investments that are no longer economically and socially viable, while the selection process for new investments to be organized from scratch under new criteria (Voinea, 2014). In this respect, the Public Investment Assessment Unit started its activity in October 2013 and the methodological norms for the prioritization of public investment projects were developed with the support of the World Bank. However, the option of private finance was less touched and the visibility of the Unit has diminished especially with the successive reorganizations of the Governments. In this context, there is a need for a legal entity inside the Government having the responsibility of running and controlling the entire operations related to public-private forms of cooperation, being responsible for establishing the strategy, the purpose and the development of these projects, and being accountable to the government and the EU.

\section{Conclusions}

This paper focuses on the needs of Romania for ensuring the functioning of the Investment Plan regarding the legal and institutional framework. Among the reasons why Romania missed the start of the Juncker Plan are the lack of proper working or essential regulations for the public-private partnerships, whose law is 
not yet operational, the absence of a national promotional institution and the long period for establishing it, the difficulties in setting connections between the public and the private entities.

In the PPPs' area, there is not a functional legislation to ensure the collaboration between the private and public sectors. The Department empowered with PPPs' attributions is almost unnoticeable in the Romanian economy, while only recently the legislation related to the PPPs was adopted. In order to foster the development of PPPs, Romania needs a functional legislative framework that regulates the institutional PPP contract. The special PPP unit with high visibility in the institutional machinery is another requirement for handling all the steps needed for the implementation of PPP programs.

Supporting the development of investment platforms and funds is essential due to their strong potential to finance greenfield or brownfield projects in infrastructure, energy and renewables. Romania has the opportunity to build investment platforms with the assistance from the EIAH not only for ensuring the functioning of the EFSI but also for improving the involvement of private actors in the economy. Finally, to encourage private companies' investments in such funds, it is useful to provide incentives, according to European practice in the field.

As regards the national promotional institutions, Romania has not decided yet to transform the EximBank in a development bank. The NPB not only represents a potential beneficiary of EFSI, but also has the mandate to direct funds in areas facing a lack of financing. In the absence of such measures as urgently as possible, the prospect of lagging behind as compared to the EU platoon is increasingly real.

Romania needs more institutional flexibility in the future. The actual exercise for adapting the legislative and institutional framework at the requirements of the investment opportunity represented by the Juncker Plan took too long. Priorities should be better defined and pursued, especially that the European Commission envisages the continuation of the EFSI at least until 2020 (Pianta, 2016) and this type of structure for supporting investments has a high potential to be further implemented at the European level (Mertens and Thiemann, 2018). A major need is the establishment of a legal entity inside the Government responsible for running and controlling the entire operations related to public-private forms of cooperation, being accountable to the government and the EU for establishing the strategy and purpose of these projects and their development.

\section{References}

Abiad, A., Furceri, D. and Topalova, P., 2015. "The Macroeconomic Effects of Public Investments: Evidence from Advanced Economies", Journal of Macroeconomics, Vol. 50, pp. 224-240.

Albu, L. L., Călin, A. C., Popovici, O. C. and Belingher, D. S., 2016. Planul de Investiţii al Comisiei Juncker şi Potenţialul Impact Asupra Economiei Româneşti, European Institute of Romania.

Barrett, T. C. and von Thadden, G., 2011. The European PPP Expertise Centre Activities in 2011. Retrieved on Nov. 9, 2018 from http://ec.europa.eu/economy_finance/events/2011/2011-11-08_ ecepec/pdf/barret_thadden_8_nov_2011_brussels_en.pdf.

Booth, L. and Starodubtseva, V., 2015. PFI: Costs and Benefits, UK Parliament House of Commons, Brief- 
ing Paper 6007.

Calin, A.C., Popovici, O.C. and Hurduzeu, G., 2017. "The Impact of the Juncker Plan on Investors' Belief", Romanian Journal of Economic Forecasting, Vol. XX, No. 3, pp. 150-165.

Crespo, D. C., 2015. "How to Close the EU Investment Gap, Federal Ministry of Science, Research and Economy", Austria, Investing in Europe's Future, 2015, pp. 3-32.

De Luna-Martínez, J. and Vicente, C. L., 2012. Global Survey of Development Banks, World Bank Policy Research Working Paper, No.5969, Washington DC.

Ernst and Young,, 2014. Global Investment Platform Convergence. Retrieved on Nov. 20, 2018 from http://www .ey.com/Publication/vwLUAssets/EY-global-investment-platform-convergencehow-should-asias-wealth-asset-managers-respond/\$FILE/EY-global-investment-platformconvergence-how-should-asias-wealth-asset-managers-respond.pdf.

European Commission and European Investment Bank, 2016. European Fund for Strategic Investments, Rules Applicable to Operations with Investment Platforms and National Promotional Banks or Institutions. Retrieved on Nov. 20, 2018 from http://www.eib.org/eib.org/infocentre/publications/ all/efsi-rules-applicable-to-operations.htm.

European Commission, 2015. Comunicare a Comisiei Către Parlamentul European şi Consiliu, Sucrând împreună Pentru Locuri de Muncă şi Creştere Economică: Rolul Băncilor Naţionale de Promovare (BNP) în Sprijinirea Planului de Investiţii Pentru Europa, COM(2015), 361, 2015.

European Investment Bank, 2014. Establishing and Reforming PPP Units Analysis of EPEC Member PPP Units and Lessons Learnt. Retrieved on Nov. 1, 2018 from http://www.eib.org/epec/resources/ publications/epec_establishing_and_reforming_ppp_units_en.pdf.

European Investment Bank, 2016. EIB Group Figures. Retrieved on Nov. 20, 2018 from http://www.eib. org/efsi/efsi_dashboard_june_16_en.jpg.

European Investment Bank, 2015. A Programme Approach to PPPs Lessons from the European Experience. Retrieved on Nov. 20, 2018 from http://www.eib.org/epec/resources/publications/epec_ programme_approach_to_ppps_en

European PPP Expertise Center, 2015. Review of the European PPP Market in 2015. Retrieved on Oct. 1, 2018 from http://www.eib.org/epec/library/epec_market_update_2015_en2.

Froud, J., 2003. "The Private Finance Initiative: Risk, Uncertainty and the State", Accounting, Organizations and Society, Vol. 28, pp. 567?589.

Garg, S and Grag, S., 2017. "Rethinking Public-private Partnerships: An Unbundling Approach", Transportation Research Procedia, Vol. 25, pp. 3789?3807.

Gordon, S., 2017, June 26. Juncker's European Investment Plan: The Rhetoric versus Reality. Retrieved on Nov. 1, 2018 from https://www.ft.com/content/90712920-138b-11e7-b0c1-37e417ee6c76.

Guldbradsen, T., 2002. "Public-Private Partnerships and State and Local Economic Development: Leveraging Private Investment", Reviews of Economic Development Literature and Practice, 16

Mertens, D. and Thiemann, M., 2017. "Building a Hidden Investment State? The European Investment Bank, National Development Banks and European Economic Governance", Journal of European Public 
Policy, Volume 26, Issue 1, pp. 23-43, DOI: 10.1080/13501763.2017.1382556.

Mertens, D. and Thiemann, M., 2018. "Market-based but State-led: The Role of Public Development Banks in Shaping Market-based Finance in the European Union", Competition and Change, Vol. 22, Issue 2, pp. 184-204.

Mullin, S. P., 2002. "Public-Private Partnerships and State and Local Economic Development, Leveraging Private Investment", Reviews of Economic Development Literature and Practice, No. 16, pp. 1-38.

OECD, 2012. Recommendation of the Council on Principles for Public Governance of Public-Private Partnerships.

Pianta, M., 2016. "Why Europe Needs a Public Investment Plan", Intereconomics, Special Issue, ZBW ? Leibniz Information Centre for Economics, DOI: 10.1007/s10272-016-0626-7.

Regulation (EU) No.1303/2013. Official Journal of the European Union, http://eur-lex.europa.eu/ legal-content/EN/TXT/PDF/?uri=CELEX : 32013R1303and:PDF

Regulation (EU) No. 2015/1017. Official Journal of the European Union, http://eur-lex.europa.eu/ legal-content/EN/TXT/PDF/?uri=CELEX : 32015R1017andfrom=RO

Rinaldi, D. and Nunez-Ferrer, J., 2017. "The European Fund for Strategic Investments as a New Type of Budgetary Instrument", CEPS Research Reports, 7.

Romanian Government, 2016. Programul legislativ al Guvernului României pentru anul 2016. Retrieved on Nov. 1, 2018 from http://www.drp.gov.ro/download.php?f=bd53d11c0cfdee5ba2fb03865633276f.

Romanian Ministry of Finance, 2015a. Proiect de LEGE privind funcţionarea Băncii de Dezvoltare a României-EximBank S.A.. Retrieved on Oct. 1, 2018 from http://discutii.mfinante.ro/static/10/ Mfp/transparenta/ProiectLegeprivindfunctionareaBanciiDezvoltareRom06112015.pdf.

Romanian Ministry of Finance, 2015b. Expunere de Motive, Lege Privind Funcţionarea Băncii de Dezvoltare a României - EximBank S.A.. Retrieved on Nov. 1, 2018 from http://discutii.mfinante.ro/static/ 10/Mfp/transparenta/ProiectLegeprivindfunctionareaBanciiDezvoltareRom06112015.pdf.

Romanian Parliament, 2000. LEGE nr.96 din 2 iunie 2000 Privind Organizarea şi Funcţionarea Băncii de Export-Import a României EXIMBANK - S.A. şi Instrumentele Specifice de Susţinere a Comerţului Exterior'. Retrieved on July 1, 2018 from http://www.cdep.ro/pls/legis/legis_pck.htp_act_text? $i d t=23205$.

Rubio, E., Rinaldi, D. and Pellerin-Carlin, T., 2016. "Investment in Europe: Making the Best of the Juncker Plan". With Case Studies on Digital Infrastructure and Energy Efficiency, Jacque Delors Institute, Studies and Reports no.109, 2016.

Voinea, L., 2014. Reforma in finantarea investitiilor publice: evaluarea investitiilor publice in vederea finantarii cu prioritate sau sistarii, Ministerul Finantelor Publice, Romania.

Wruuck, P., 2015. Promoting Investment and Growth: The Role of Development Banks in Europe, Deutsche Bank Research. 